\title{
$\boldsymbol{E}$

2013, Vol. 1, No. 1

\section{The Determinants of FDI Flows from the EU-15 to the Visegrad Group Countries - A Panel Gravity Model Approach}

\author{
Liwiusz Wojciechowski
}

\begin{abstract}
A B S T R A C T
Objective: The objective of this paper is to evaluate determinants of the general FDI flow to Visegrad countries and the effect of participation in EMU and EU.

Research Design \& Methods: It was decided to investigate how augmented Gravity Model of trade allows identifying and evaluating the significance of pull and push factors of FDI. In an empirical analysis of panel data Hausman-Taylor estimator was used because of the time-invariant variables presence.
\end{abstract}

Findings: While investment decisions regarding the choice of country are determined by the size of the target market, the distance is still a negative factor in creation of FDI volume. Additionally, it was proven that membership in EMU, differences in taxation, historical background, access to the sea and prices stability have significant impact of FDI stock formation in each country belonging to V4. Is was also noted that Poland became a leader of the V4 as well as EU-12 FDI market sourcing from the old EU Member States.

Implications \& Recommendations: It is necessary to develop an "FDI attracting mechanism" using existing resources. Business regulations and taxation policy as well as main macroeconomic variables which are responsible for the economy standing are also examined as attracting the FDI flow.

Contribution \& Value Added: The originality of this work lies in studying some aspects of FDI inflow into the group of both similar and different countries in economic measures terms.

\begin{tabular}{ll}
\hline Article type: & research paper \\
Keywords: & Visegrad countries (V4); FDI; gravity theory; panel \\
JEL codes: & C33, F21
\end{tabular}

Published by Centre for Strategic and International Entrepreneurship - Krakow, Poland

\section{Suggested citation:}

Wojciechowski, L., (2013). 'The Determinants of FDI Flows from the EU-15 to the Visegrad Group Countries - A Panel Gravity Model Approach'. Entrepreneurial Business and Economics Review, 1(1), pp. 7-22. 


\section{INTRODUCTION}

Business regulations and taxation policy as well as main macroeconomic variables which are responsible for the economy standing are also examined as attracting the foreign direct investment (FDI) flow. The objective of this paper is to evaluate determinants of the general FDI flow to Visegrad countries and the effect of participation in EMU and EU. The analysis is based on the data for 2001-2011. The gravity equation is used to evaluate the importance of host countries potential factors. Other determinants of bilateral FDI flows such as market size measured by GDP terms, distance, price stability, infrastructure development, common border and language and cultural similarities are also important part of the equation. Despite the existence of numerous papers about the structure and dynamic of Central and Eastern European (CEE) countries FDI determinants there is still a lack of empirical studies about the individual characteristics with reference to the theory of capital movement. Dunning decided to distinguish factors attracting FDI from EU-15 to V4. This is important for economic policy because 3 out of $4 \mathrm{~V} 4$ countries still remain outside the EMU, which as evidenced by empirical studies, limits the inflow of FDI. Taking into account this limitation, it is necessary to develop an "FDI attracting mechanism" using existing resources.

\section{LITERATURE REVIEW}

\section{FDI Theory}

Foreign direct investment is explained as an international investment within the balance of payment account. "According to the IMF and OECD definitions, direct investment reflects the aim of obtaining a lasting interest by a resident entity of one economy (direct investor) in an enterprise that is resident in another economy (the direct investment enterprise)" (Duce, 2003, p. 2). Direct investment capital transactions are considered as including three basic components (Duce, 2003): equity capital, reinvested earnings or other investment capital. Data on FDI flows and stocks are published by several independent sources. OECD and Eurostat offer comparable and reliable data ${ }^{1}$.

In the current globalized world, capital is getting more and more flexible and mobile. Among the different types of sources of capital, FDI are considered as the safest and the most beneficial form of international capital flows. Foreign capital operates on the economy of the supply, as a kind of complement deficiencies accumulation. Favorable factors of systemic and structural FDI are a way to gain access to modern techniques and technologies both in the production and management and markets. Therefore, as a particularly important element of government policy, administration should permanently develop a workable mechanism for attracting foreign capital (Brenton et al., 1999; Estrin \& Milica, 2013; Rajan \& Hattari, 2008; Estrin \& Klaus, 2008; Egger \& Pfaffermayr, 2004; Turan \& Sotrios, 2013).

\footnotetext{
${ }^{1}$ In this study Eurostat stock FDI from EU-15 to EU-12 in 2000-2011 are considered. Position at the end of the period $=$ Position at the beginning of the period + FDI flows + price changes + exchange rate changes + other adjustments.
} 
From the point of view of the host country FDI substitutes for imports. There is ample empirical evidence indicating the substitution relationship between exports and the size of the flows of foreign direct investment led to the country of importation (Ahmed et al., 2008; Mauro, 2000). Direct foreign investments are divided into two types, considered them in a horizontal and vertical as well as brown field and greenfield investment (Alan \& Bevan, 2000). In theoretical terms, the impact of FDI on the differences in the competitive advantage associates with the concept of Porter (1979) forces. Porter identified four main groups of factors that contribute to gain an advantage (Julio et al., 2013):

- work in productive factors,

- demand factors,

- the corresponding partition structure,

- conditions of formation,

- organization and management.

However, the basic theory of FDI determinants engaging movement of capital is Dunning's eclectic OLI paradigm. Under the acronym OLI hides the key explanatory factors, according to Dunning, making direct investments (Ownership, Localization, and Internalization). Dunning suggests that taking FDI is due to the interaction of three conditions. Ownership advantages of an oligopoly, the existence of specific favorable locational factors and the occurrence of the benefits of internalization advantage over externalization companies. In turn, the method of classification motives behind foreign investment developed by J. Dunning, points to the search for suitable resources that serve maintaining or improving the international competitiveness of enterprise (Dunning, 1998). Dunning singled out four main themes of the project (Dunning, 1998; Wach 2012, p. 69; Daszkiewicz \& Wach, 2013, p. 37):

- resource-seeking (seeking access to natural resources and transport infrastructure),

- market-seeking (seeking access to new markets, a skilled workforce, suppliers and subcontractors, better organization of the market at the level of economic, institutional and legal),

- efficiency-seeking (seeking increased efficiency due to the reduction of manufacturing costs, facilitating doing business, incentives for investors, flexibility, and increasing the quality of work on the part of the workforce),

- strategic asset-seeking (seeking access to strategic resources related primarily to the know-how, technology, manufacturing, distribution, etc.).

\section{The Gravity Model in FDI Research}

The gravity model is a major simplification when it comes to terms of dealing with the variables affecting positively on the volume of trade (GDP) and negative (distance). Mostly authors use the gravity model with an additional vector of explanatory variables. They are described by examining significance of the relationship and direction and the impact of the variable on the phenomenon. Model has an ability to be augmented by quantitative and qualitative variables, which can make that countries seemingly similar in terms of GDP per capita or neighbouring states (Suder et al., 2012) trade less than the others. However it does not state as a denial of the gravity model fact, because it is like any other kind of simplification and refers to the general correctness (Brun et al., 2005). The gravity model has become as defined in literature a 
"work horse" to describe international or regional trade, foreign investment and other socioeconomics facts such as migrations.

Literature abounds with varied approaches in researching specific hypotheses as well as considering way of expression variables. In recent years, there are more and more publications dealing with gravity model of trade considering trade or investment flows (Babula \& Kamińska, 2013)

Focusing on the theme, we refer to the approach of analysing FDI flows by DeRosa (2006). He describes gravity model based on bilateral trade flows estimated on the panel of 170 countries in the period 1976-2006. The model included binary variables reflecting participation in free trade areas (FTAs) (Konstantinos et al., 2010). DeRosa suggested in contrast to the classical model of gravitational set of variables such as $\Pi$ ij GDP (or difference between GDP in partner and host country) and expressed in per capita terms, as well as variables representing the historical and geographical conditions (common language, boundaries, continent, common colonizer and belonging to communities like EU, Mercosour). The author also noted that there are correlations between trade and foreign direct investments, namely, the greater resources of FDI are located in the partner country the greater the volume of trade between the countries under consideration. DeRosa also pointed out that the gravity model can be used to predict the effects of further economic integration, which should be taken into account in decision-making at the international level.

P. Folfas (2011) estimated the gravity model of FDI flow between members of the EU (EU-27) with particular emphasis on the importance of taxes. The model combined not only geographical distance but also other variables to illustrate the economic distance: membership in the euro zone, cultural similarity, period of membership in the EU. In addition to the model there were included variables representing the tax policy towards enterprises (CIT). Model confirmed the importance of the offshore financial centres (Cyprus, Luxembourg and Malta), which play a very important role in the flow of capital in the European Union. The presence of variable time constants (invariants) imposed on the use of the H-T estimator (Hausman \& Taylor, 1981). By the empirical study showing that the flow of foreign investment is conditioned in the EU (EU-27) by the size of GDP (total and per capita) and the distance factor. The estimation results confirm the meaning of the motto of the European Union "In varietate concordia". The study showed that the tax disparity between countries is a factor that stimulates the flow of FDI. In addition, cultural similarity factor implements a positive impact on foreign direct investment. FDI in Visegrad Group countries are also matter of concern. Authors analyze the structure and the type of FDI. Some publications take into account the dynamics of changes due to the accession V4 to the EU (Hunya \& Richert, 2011; Babunek, 2012; Jambor, 2013). Nevertheless there is still a lack of studies that would show key factors of attracting FDI internationally respecting V4 countries.

\section{MATERIAL AND METHODS}

\section{Goals and Hypothesis}

This paper aims at deciding, which factors determinate FDI flow from EU-15 to the Visegrad Group. from EU-15 to the Visegrad Group. Referring to the classical gravitation model we verify whether and, if so, how the "size factors" determine the volume of FDI 
flows. Interesting from the point of view of this study is whether the larger economy tends to accumulate a larger portion of total investment flows and whether the distance actually has a negative reflection on the volume of these flows. The model was further extended to include elements that are considered direct and contributory factors inhibiting the influx of investments in order to answer the question whether these factors equally determine the size of FDI between countries that invest a host. There will be verifies, inter alia, the hypothesis of a significant negative relationship between the level of wage costs of the host country and the size of foreign investment in the country. In fact, it should be vital not only for empirical research but most of all for government policy, to understand how such factors as: exchange rate volatility, stability, inflation, interest rates, protectionism, unemployment, level of education or general investment climate, determine competitiveness of a country in the international sourcing of foreign capital. Knowledge of the significance and influence of the above as well as many other variables can influence the monetary and fiscal policies in order to enhance the competitive position of the country.

\section{Variables and Data Sources}

The choice of the "traditional variables" is based on the existing theory and empirical research of the literature. The model also takes into account other variables; the choice was dictated by the nature of the studied phenomenon. As a result, the set of explanatory variables the model uses can be divided into three major groups. The first are the variables taken from the traditional gravity model (size of the market within the meaning of GDP per capita, population, geographical distance). The estimation procedure considers different combinations of variables (in terms of total per capita, as the difference, the product of variables), referring to examples from the literature issues.

The second group of separable variables are expressed as factors stimulating or inhibiting the influx of foreign investment to host countries. The FDI has numerous variables, which will be examining actual significance in relation to the individual economies in the sense of obtaining foreign direct investment. The third group included all other variables that could potentially contribute to improvement of the quality of estimates. Among these, there are many binary variables. There should be taken into account such elements as institutional membership groups (EU, EMU, OECD, CEFTA, BAFTA, ERM II, the access to the sea). Macroeconomic data come from Eurostat database, UNTCAD and official websites of national banks of individual countries. Financial data were collected from sites Bloomberg.com, Tradingeconomics.com.

\section{Research methods}

Cross-sectional (panel) data, are data that describe a certain group of individuals as in the case of cross-sectional data, with the difference that the observations are made in more than one period. Panel data are indicated by yit, where $i=1, \ldots, N, t=1, \ldots, T$. Panel models are both static and dynamic forms. The overall formula of the static model, which we will consider is (1):

$$
y_{i t}=\beta_{0}+\beta^{\prime} x_{i t}+\alpha_{i}+v_{t}+u_{i t}
$$


where :

$\beta_{0}$ - is the intercept,

$\beta^{\prime}$ - is the vector of structural parameters,

$\alpha_{i}$ - is the result of individual i-unit,

$v_{t}$ - effect of periodic t-period,

$u_{i t}$ - the assumption of random error component.

Referring directly to the model (1), where it is held and insignificance of the individual and periodic effects panel appears homogeneous. It comes down to the fact that the relationship between variables in a statistical sense is not significantly different for the test units and periods. The assumption in the model such attempt is a homogeneous which means in practice that the analyzed individuals have a similar specification. This in turn should reveal the same or tightly close together structural parameters of the model to all individuals and periods. Any deviation while (the rest of the model) are the result of random noise. Often, however, at least one group of effects is important. The panel is then the nature of heterogeneous and, depending on whether only one group of effects is important that both models are considered one or two-way (one-way model/two-way model). These effects $\alpha_{i}$ and $v_{t}$ effects may be of a fixed (unchanging in time or fixed for a specific entity) independent random factors $u_{i t}$ (Baltagi, 2005). They also have a random character with a certain distribution, which depends on the random component. In the first case we have to deal with the model with fixed effects (called Fixed Effects) and the second with the model with random effects (called Random Effects). RE models with greater precision of estimates. FE analysis does not allow time invariants (Baltagi, 2005).

The consequence of the inclusion of the model variables which values do not change over time (eg. a common border of neighbouring countries, access to the sea) is collinear with the individual fixed effects. This in turn rules out the use of the fixed effects model. When the explanatory variables found to be correlated with the interfering component is also not permitted to use model RE model. Proposed several solutions to this problem: Estimation of the use of the FE estimator Hausman-Taylor, The Chamberlain approach of RE model (Chamberlain \& Moreira, 2006).

According to the procedure Hausman-Taylor variables included in the vector $\mathrm{X}$ are split into two parts according to the criterion of variation in time. On this basis, the provision of the model is as follows (2):

$$
y_{i t}=z^{\prime}{ }_{i} \gamma+x^{\prime}{ }_{i t} \beta+\alpha_{i}+\xi_{i t} ; i, t ; i=1, \ldots, N ; t=1, \ldots, T
$$

where:

$$
\begin{aligned}
& z^{\prime}{ }_{i} \text { is a vector of variables assuming constant values during, } \\
& x^{\prime}{ }_{i t} \text { is a vector of variables over time. }
\end{aligned}
$$

The model assumes (3) and (4):

$$
E\left(\xi_{i t} \mid z^{\prime}{ }_{i t}, \alpha_{i}\right)=0
$$




$$
\hat{\gamma}=\left(\frac{1}{N} \sum_{i=1}^{N} z_{i} z^{\prime}\right)^{-1}\left(\frac{1}{N} \sum_{i=1}^{N} z_{i}\left(\overline{y_{i}}-\overline{x_{i}^{\prime}} \hat{\beta_{F E}}\right)\right)
$$

Where $\beta_{F E}$ is a vector of parameter estimates $\beta$ estimated in the $F E$ model, and expected values of $\left(y_{i}\right),\left(x_{i}\right)$ are the arithmetic means of individuals in-time. Estimation of the model with variable time constant according to the procedure Hausman-Taylor is twofold. In the first phase are estimated structural parameters $\beta$ of the $F E$ model, and given that the variables are constant over time, as has been said previously, aligned with the individual effects, it is discarded. In the second stage, using the estimator $\gamma$ estimated parameters of the variables constant in time with regard to the arithmetic average of these variables and parameter estimates $\beta$.

\section{The Use of the Gravity Model}

The gravity model appears as an adaptation of the law of universal gravitation for socioeconomic phenomena like trade, investment flows, and migrations. Under the concept of gravity model of international trade we mean the model proposed independently by Tinbergen in 1962 and Pyhonen in 1963. This formula was to explain the bilateral flows between countries taking into account the size of countries and the limiting factor in trade which have identified the costs of movement between two countries. This proxy of resistance factor was the geographical distance (Anderson, 1979) according to the equations (5) and (6):

$$
\begin{gathered}
X_{i j}=K \frac{Y_{i}{ }^{a} Y_{j}^{b}}{D_{i j}^{c}} \\
\ln X_{i j}=\ln K+a \ln Y_{i}+b \ln Y_{j}-\beta \ln D_{i j}
\end{gathered}
$$

where:

$D$ - distance, transportation costs,

$K$ - factor proportionality,

$X_{i j}$ - the volume of trade between countries $\mathrm{i}$ and $\mathrm{j}$,

$Y_{i}, Y_{j}$ - the size of the economy of the country $i$ and $\mathrm{j}$, expressed by GDP, GDP per capita, the size of the market, population size, etc.

According to the formula, the volume of trade is proportional to the product of the size of these countries (in terms of GDP or other variable imaging market size) in ceteris paribus terms, and the volume decreases with increasing distance between two countries, which generates additional costs that reduce the attractiveness of trade. However, there are many variables which can embody economic masses of locations. Economic size can be measured by: gross national product, gross domestic product and population, gross domestic product per capita or endowment of production factors (absolute value or per capita). Therefore, there are a great number of methods of measuring gross domestic products: in current prices, in constant prices or in purchasing power parity. It is debatable which measure is the most adequate for gravity models (Folfas, 2011; Czarny \& Folfas, 2011). 


\section{RESULTS AND DISCUSSION}

For the general background it has been decided to isolate the largest, in relative terms the position of FDI, host countries relative to investing countries. Choosing the highest values, indicated for each EU-15 country, from 1 to 4 countries we can accept that Austria, Belgium, France, Spain, Netherlands, Luxemburg and Germany invest mainly in Czech Republic. Austria, Belgium, Netherlands, Luxemburg and Germany invest in Hungary. All EU-15 (without Greece and Austria) allocated the largest part of its investments in Poland.

Table 1 presents the inward stock of FDI in Poland in relation to the total outward FDI from EU-15 countries co-creating the EU-27 (the 12 countries that joined the EU after 2004) in the period 2000-2011. Table 2 presents the value of interest accumulated from foreign direct investment (inward stock) from the EU-15 and Poland in the decomposition of partner countries in the 2000-2011. The analysis of this data allows drawing some initial conclusions:

- the structure of stock FDI in Poland is rather stable,

- main partners of Poland are the Netherlands, Germany, France, Luxembourg (since 2007),

- there is a noticeable systematic decrease in case of Netherlands and Germany in relation to Luxembourg.

Table 1. Inwardstock FDI in Poland as total outward FDI from EU-15 to EU-12 (in \%)

\begin{tabular}{|l|r|r|r|r|r|r|r|r|r|r|r|r|}
\hline Partner/Year & $\mathbf{2 0 0 0}$ & $\mathbf{2 0 0 1}$ & $\mathbf{2 0 0 2}$ & $\mathbf{2 0 0 3}$ & $\mathbf{2 0 0 4}$ & $\mathbf{2 0 0 5}$ & $\mathbf{2 0 0 6}$ & $\mathbf{2 0 0 7}$ & $\mathbf{2 0 0 8}$ & $\mathbf{2 0 0 9}$ & $\mathbf{2 0 1 0}$ & $\mathbf{2 0 1 1}$ \\
\hline Austria & 25 & 21 & 20 & 13 & 16 & 13 & 9 & 9 & 8 & 9 & 9 & 9 \\
\hline Belgium & 45 & 43 & 42 & 34 & 45 & 43 & 42 & 34 & 36 & 30 & 32 & 35 \\
\hline Denmark & 48 & 53 & 50 & 45 & 48 & 47 & 43 & 43 & 42 & 45 & 44 & 51 \\
\hline Finland & 15 & 17 & 17 & 13 & 13 & 19 & 19 & 22 & 23 & 21 & 21 & 22 \\
\hline France & 78 & 71 & 65 & 56 & 58 & 51 & 49 & 46 & 43 & 46 & 53 & 53 \\
\hline Greece & 0 & 10 & 2 & 2 & 2 & 1 & 1 & 1 & 1 & 0 & 0 & 8 \\
\hline Spain & 93 & 87 & 83 & 37 & 53 & 25 & 37 & 40 & 39 & 40 & 44 & 60 \\
\hline Netherlands & 51 & 50 & 44 & 33 & 35 & 33 & 32 & 29 & 27 & 25 & 29 & 24 \\
\hline Ireland & 82 & 74 & 73 & 75 & 74 & 72 & 66 & 56 & 49 & 49 & 66 & 38 \\
\hline Luxemburg & 43 & 42 & 40 & 27 & 33 & 47 & 49 & 39 & 39 & 46 & 46 & 52 \\
\hline Germany & 47 & 45 & 40 & 27 & 28 & 28 & 28 & 31 & 30 & 33 & 30 & 27 \\
\hline Portugal & 96 & 99 & 92 & 83 & 81 & 73 & 73 & 68 & 68 & 67 & 71 & 72 \\
\hline Sweden & 37 & 37 & 34 & 30 & 31 & 29 & 33 & 34 & 36 & 43 & 41 & 46 \\
\hline Italy & 78 & 59 & 55 & 38 & 42 & 30 & 40 & 59 & 42 & 71 & 64 & 55 \\
\hline UK & 42 & 31 & 36 & 29 & 30 & 25 & 27 & 36 & 34 & 33 & 36 & 35 \\
\hline
\end{tabular}

Source: Eurostat

To answer the question, which part of foreign investment from the individual EU-15 countries is "intercepted" by V4 countries in 2000-2011, the appropriate calculations on the basis of which lead to the regularity is to be conducted. There was a permanent decrease in the percentage of Austrian investment in V4 as compared to other EU-12 countries. A similar situation occurred in the case of Italy and the UK. The opposite trend was observed in case of Sweden and Finland (table 3). Analyzing the structure and dynamic (table 4), it can be seen that the largest investments in V4 come from Austria, France, the Netherlands and Germany and Luxembourg (the growth rate of stock FDI of Luxembourg in V4 reached $51 \%$ annually in the examined period). 
Table 2. Inward stock FDI in Poland from EU-15 break down by partner country in the years 2000-2011 (in \%)

\begin{tabular}{|l|r|r|r|r|r|r|r|r|r|r|r|r|}
\hline Partner/Year & $\mathbf{2 0 0 0}$ & $\mathbf{2 0 0 1}$ & $\mathbf{2 0 0 2}$ & $\mathbf{2 0 0 3}$ & $\mathbf{2 0 0 4}$ & $\mathbf{2 0 0 5}$ & $\mathbf{2 0 0 6}$ & $\mathbf{2 0 0 7}$ & $\mathbf{2 0 0 8}$ & $\mathbf{2 0 0 9}$ & $\mathbf{2 0 1 0}$ & $\mathbf{2 0 1 1}$ \\
\hline Austria & 4 & 4 & 4 & 5 & 6 & 6 & 4 & 4 & 4 & 4 & 4 & 4 \\
\hline Belgium & 2 & 3 & 4 & 4 & 5 & 4 & 4 & 4 & 4 & 4 & 3 & 3 \\
\hline Denmark & 3 & 4 & 4 & 4 & 3 & 3 & 3 & 3 & 3 & 3 & 2 & 2 \\
\hline Finland & 1 & 1 & 1 & 1 & 1 & 2 & 1 & 1 & 1 & 1 & 1 & 1 \\
\hline France & 15 & 19 & 17 & 18 & 16 & 15 & 14 & 14 & 13 & 14 & 15 & 15 \\
\hline Greece & 0 & 0 & 0 & 0 & 0 & 0 & 0 & 0 & 0 & 0 & 0 & 1 \\
\hline Spain & 2 & 2 & 2 & 1 & 2 & 2 & 3 & 4 & 4 & 4 & 4 & 7 \\
\hline Netherlands & 31 & 30 & 30 & 28 & 28 & 26 & 24 & 23 & 23 & 22 & 22 & 18 \\
\hline Ireland & 1 & 1 & 2 & 2 & 2 & 2 & 2 & 2 & 2 & 2 & 3 & 1 \\
\hline Luxemburg & 2 & 1 & 1 & 2 & 3 & 6 & 10 & 10 & 11 & 11 & 10 & 12 \\
\hline Germany & 24 & 23 & 22 & 22 & 20 & 20 & 20 & 20 & 19 & 20 & 16 & 16 \\
\hline Portugal & 1 & 1 & 1 & 1 & 1 & 1 & 1 & 1 & 1 & 1 & 1 & 1 \\
\hline Sweden & 4 & 4 & 4 & 5 & 5 & 5 & 5 & 5 & 6 & 6 & 5 & 7 \\
\hline Italy & 4 & 4 & 4 & 4 & 4 & 4 & 5 & 5 & 5 & 4 & 5 & 5 \\
\hline UK & 5 & 5 & 5 & 4 & 5 & 4 & 5 & 5 & 5 & 5 & 8 & 6 \\
\hline Total & 100 & 100 & 100 & 100 & 100 & 100 & 100 & 100 & 100 & 100 & 100 & 100 \\
\hline
\end{tabular}

Source: Eurostat

Table 3. Part of total EU-15 stock FDI in EU-12 invested only in V4 countries in the years 20002011 (in \%)

\begin{tabular}{|l|r|r|r|r|r|r|r|r|r|r|r|r|}
\hline Partner/Year & $\mathbf{2 0 0 0}$ & $\mathbf{2 0 0 1}$ & $\mathbf{2 0 0 2}$ & $\mathbf{2 0 0 3}$ & $\mathbf{2 0 0 4}$ & $\mathbf{2 0 0 5}$ & $\mathbf{2 0 0 6}$ & $\mathbf{2 0 0 7}$ & $\mathbf{2 0 0 8}$ & $\mathbf{2 0 0 9}$ & $\mathbf{2 0 1 0}$ & $\mathbf{2 0 1 1}$ \\
\hline Austria & 95 & $\mathbf{8 2}$ & $\mathbf{7 9}$ & $\mathbf{8 5}$ & $\mathbf{7 7}$ & 63 & 55 & 56 & 56 & 58 & 60 & 57 \\
\hline Belgium & 99 & 100 & 94 & 90 & 92 & 90 & 89 & 90 & 90 & 85 & 85 & 84 \\
\hline Denmark & 65 & 61 & 59 & 62 & 66 & 61 & 58 & 60 & 65 & 66 & 62 & 70 \\
\hline Finland & 25 & 27 & 20 & 34 & 36 & 40 & 30 & 34 & 34 & 39 & 39 & 31 \\
\hline France & 98 & 94 & 94 & 94 & 94 & 85 & 82 & 81 & 79 & 80 & 82 & 80 \\
\hline Greece & 3 & 12 & 2 & 2 & 2 & 1 & 1 & 1 & 1 & 0 & 0 & 8 \\
\hline Spain & 99 & 99 & 100 & 99 & 98 & 96 & 92 & 86 & 83 & 82 & 83 & 86 \\
\hline Netherlands & 98 & 96 & 95 & 95 & 94 & 85 & 83 & 81 & 80 & 77 & 78 & 74 \\
\hline Ireland & 84 & 85 & 77 & 83 & 86 & 80 & 73 & 68 & 70 & 70 & 76 & 40 \\
\hline Luxemburg & 99 & 99 & 90 & 87 & 89 & 88 & 90 & 92 & 87 & 91 & 90 & 89 \\
\hline Germany & 95 & 93 & 90 & 92 & 91 & 87 & 86 & 84 & 79 & 82 & 77 & 78 \\
\hline Portugal & 97 & 99 & 95 & 94 & 94 & 85 & 82 & 88 & 87 & 88 & 88 & 87 \\
\hline Sweden & 47 & 45 & 44 & 46 & 45 & 43 & 46 & 46 & 50 & 54 & 53 & 55 \\
\hline Italy & 90 & 83 & 83 & 80 & 79 & 70 & 66 & 56 & 52 & 44 & 72 & 64 \\
\hline UK & 81 & 84 & 74 & 76 & 71 & 77 & 71 & 60 & 48 & 54 & 62 & 60 \\
\hline
\end{tabular}

Source: Eurostat

\section{Expectations, Calculations and Results}

In the previous chapter there was presented the set of potential explanatory variables of the model there. Coming directly from the formula gravity model estimation is started from the linearized model to estimate dependence between the volume of the stock of FDI GDP per capita of the host and investing country as well as the geographical distance between them. This model would serve as a reference point to the expansion of additional elements in the vector of explanatory variables. While only estimation shows which variables significantly affect the dependent variable, we formulate expectations about the parameters standing by these variables. Referring to the many papers in which they modeled FDI in the formula of gravity model, positive 
parameters with variables expressing the size of the market economy and a partner of the host country are expected. At the same time negative coefficient on the variable expressing the geographical distance (as a destimulant), a factor expressing the transport costs to reach the market, its diversity, etc. is expected. While this parameter with variable Dist will probably be negative for much of particular interest are the effects of periodic, e.g. if the distance factor in terms of globalization negated or not. We expect that the bordering effect with each country, in most cases should encourage the expansion of FDI. Similarly, it is expected that access to the sea can advantageously affect the volume of FDI deposited there, because of the enhanced transport capacity (Paas \& Tafenau, 2005). In some studies authors consider the size of the economy as the size of population that makes potentially more or less absorbent market. We expect, the greater the number of residents in the host country, the greater value of FDI is invested. In the literature authors often explores the impact of the "soft factors" on the intensity of trade, and therefore we decided to investigate whether the fact the using common language as well as historical and cultural ties are reflected in the volume of FDI (Iwasaki \& Saganuma, 2013).The model will test set of binary variables expressing belonging to different groupings of integration (e.g. EU, EMU). In this case, the expected positive impact on foreign direct investment flows between countries belonging to the same group. Interesting may be the results of the periodic analysis of the effects related to the accession to the European Union. The accession should positively affect because of possibility of free movement of capital across countries, including FDI.

Table 4. Value of stock FDI in V4 from EU-15 in the years 2000-2011 (in million EUR)

\begin{tabular}{|l|r|r|r|r|r|r|r|r|r|r|r|r|}
\hline Partner/Year & $\mathbf{2 0 0 0}$ & $\mathbf{2 0 0 1}$ & $\mathbf{2 0 0 2}$ & $\mathbf{2 0 0 3}$ & $\mathbf{2 0 0 4}$ & $\mathbf{2 0 0 5}$ & $\mathbf{2 0 0 6}$ & $\mathbf{2 0 0 7}$ & $\mathbf{2 0 0 8}$ & $\mathbf{2 0 0 9}$ & $\mathbf{2 0 1 0}$ & $\mathbf{2 0 1 1}$ \\
\hline Austria & 4579 & 6031 & 6542 & 11959 & 15224 & 17591 & 20105 & 25665 & 28526 & 30985 & 32602 & 30715 \\
\hline Belgium & 0 & 1563 & 3186 & 3800 & 4933 & 5538 & 6317 & 9616 & 9408 & 11040 & 10025 & 10219 \\
\hline Denmark & 1251 & 1577 & 1565 & 1886 & 2505 & 2884 & 3248 & 4280 & 4348 & 4537 & 4508 & 4237 \\
\hline Finland & 388 & 462 & 380 & 1081 & 1351 & 2006 & 1483 & 1994 & 1994 & 2239 & 2489 & 1844 \\
\hline France & 5642 & 9537 & 9175 & 11201 & 13622 & 15986 & 18288 & 23510 & 23341 & 25010 & 29730 & 28649 \\
\hline Greece & 4 & 28 & 22 & 27 & 30 & 37 & 55 & 48 & 48 & -10 & 7 & 728 \\
\hline Spain & 752 & 686 & 691 & 1444 & 2253 & 5366 & 6360 & 7506 & 7562 & 8576 & 10144 & 12423 \\
\hline Netherlands & 17263 & 21948 & 24691 & 30862 & 39279 & 42251 & 49705 & 64193 & 66380 & 70606 & 78851 & 69225 \\
\hline Ireland & 437 & 551 & 645 & 908 & 1328 & 1467 & 1918 & 2676 & 3045 & 3455 & 4441 & 954 \\
\hline Luxemburg & 0 & 445 & 1234 & 2914 & 4719 & 6767 & 13955 & 23434 & 22741 & 22149 & 26175 & 27048 \\
\hline Germany & 14134 & 18181 & 18855 & 27996 & 34253 & 39999 & 47961 & 51262 & 49050 & 51780 & 54785 & 58831 \\
\hline Portugal & 180 & 327 & 221 & 224 & 330 & 459 & 531 & 798 & 907 & 984 & 1729 & 1504 \\
\hline Sweden & 1629 & 1716 & 2110 & 2789 & 3696 & 4712 & 5170 & 6143 & 7416 & 8091 & 8048 & 10919 \\
\hline Italy & 1841 & 2739 & 2848 & 3521 & 4546 & 6441 & 7000 & 4929 & 5425 & 3245 & 11774 & 9450 \\
\hline UK & 2314 & 3916 & 2983 & 4072 & 4626 & 8273 & 9609 & 7652 & 6201 & 7554 & 10726 & 9910 \\
\hline
\end{tabular}

Source: Eurostat

One of the reasons the expansion of companies into foreign markets are the benefits of a lower tax rate compared to the home market. It is therefore reasonable to say that the greater the difference between the rate of corporation tax between the partner country and the host country, the more likely the investment in a country with a lower load will be carried out. As part of the search for efficiency transnational corporations seeking investment location noting, inter alia, on labor costs, therefore, 
are expected to be negative evaluation parameters before variables expressing income workers (in decomposition for people with secondary and higher education).

Referring to the Dunning's (1998) classification, the company guided by motives resource seeking investments will be located in countries with identified resources of raw materials, hence the expected positive assessment of the structural parameter and variable e.g. Res, infra.

Dunning singled out market-seeking motive associated with the search for access to new markets, a skilled workforce, suppliers and subcontractors, better organization of the market at the level of economic, institutional and legal. It can be expected that the more countries spend on education and research and development the more likely developed countries will invest in them, given their potential. Based on the Doing Business report we choose three variables (Procedures, Protection, Tax-rate/profit). For a foreign investor additional risk factors may be an increased number of administrative and legal procedures (expected negative sign with variable structural parameter Procedures). At the same time, foreign investors can look at the dynamics of changes in these indicators and based on it to make decisions. It is expected to be positive when the variable parameter expresses the index of investor protection in the host country and the negative index expresses the share of corporate tax in profits.

It was decided to examine the impact of exchange rate volatility in the host country of the size of investment in the country. From the point of view of an investor greatest risk is not so much the possibility of losses resulting from the settlement of foreign exchange, (which in fact can be significantly reduced by means of an option strategies), but the same variation of the exchange rate, expressing the uncertainty of investors in the foreign exchange market, which is a derivative of the situation in the real economy. Therefore, negative coefficiency on the variable expressing the volatility of the exchange rate of the euro against the host country is expected. At the same time the observed effects may be of interest periodically in the case of countries which joined the ERM II, the aim of which is to stabilize the exchange rate (DeRosa, 2006).

Central and Eastern European countries have generally higher yield government debt and higher inflation than the EU-15. These values correlated positively the actual return on investment in the country. It is therefore expected that the higher are the rates, including the EU-15 lead in their expansion in a limited way.

High level of unemployment in the market potential of the host country may provide additional incentives for foreign investors, or it may offer a wage rate which deviates little from the average level of wages in the country. The emergence of new vacancies will reduce unemployment in the host country, also, benefits businesses efficiency of a partner country. Hence, positive evaluation parameter of the variable expressing the level of unemployment in the host country is expected (Dunning 1998).

Foreign investors may attach importance not only to the absolute changes in key economic categories such as GDP, but also to the relative changes in the short, medium and even long term. Positive evaluation parameter of the variable GDP per capita $\mathrm{y} / \mathrm{y}$ rate, expressing the rate of growth of GDP per capita in PPS market prices of the host country year to year. Based on this variable periodic moving average which is 3 proxy the medium level of economic growth in the V4 was constructed. It is expected that foreign investors will be willing to invest capital in countries with not only high expected rate of growth, but also a stable one. This was done analogously to the 
analysis of the impact of changes in prices of stock indices (the average rate of return on the capital market) should have a positive impact on the expectations of foreign investors, as well as on their specific investment decisions, expressing the location of FDI in the country. At the same time one cannot exclude lack of investor's indifference to increased investment risk reaching hand in hand with a higher expected rate of return on capital in the country.

Developed database building the extended vector of explanatory variables the model let us define the key determinants of the size and direction of flow of foreign direct investment from the EU-15 countries to V4.

As mentioned earlier, panel regression is used in the study. The following is the panel model which is estimated, explaining bilateral inward stock foreign direct investments from each partner $(i ; i=1, \ldots, 15)$ country from old EU-15 to 4 Visegrad host country $(j ; j=1, \ldots, 4)$. The sample covers the period $2001-2011^{2}$. The applied gravity model is estimated in terms of natural logarithms (7):

$$
\ln \text { FDIstock }_{i j, t}=\beta^{\prime} \ln G D P_{i, t}+\beta^{\prime} G D P_{j, t}+\beta^{\prime} \ln D I S T_{i j}+\beta^{\prime} Z_{i j, t}+\alpha_{i}+\lambda_{t}+u_{i, t}
$$

where:

$$
\begin{aligned}
& \alpha_{i} \text { - individual effect, } \\
& \lambda_{t} \text { - time effect, } \\
& u_{i, t} \text { - i.d.d.error term, } \\
& i, j, t \text { - indexes respectively for: partner economy, host economy and year, } \\
& D_{i j} \text { - geographic distance between capitals of partner and host country }(\mathrm{km}) \text { (time invariant), } \\
& Z_{i j, t} \text { - vector of other variables which potentially affecting on bilateral FDI flow }{ }^{3}, \\
& G D P_{i(j), t} \text { - GDP per capita PPS of partner (host) economy in year } t \\
& F D I s t o c k_{i j, t} \text { - inward stock FDI into host economy coming from partner economy in year t. }
\end{aligned}
$$

By using the gravity model it has been proved that FDI inward stock in Visegrad countries from EU-12 are determined by variables such as: GDP per capita of host and partner economy, distance, access to sea, medium-term rate of growth, membership in the EMU. However, based on the research sample, membership in the EU, OECD, CEFTA significantly affect the flow of FDI as well as rate of unemployment, common border, cultural similarity. It probably demonstrates further mobility of capital, which pays no attention to the presence of boundaries in the search for efficiency and economies of scale. The analysis of data suggests that foreign investors are interested rather in medium-term dynamics of the GDP of the state, than in just annual growth rates. Based on empirical research we accept statement that the extended gravity model of international trade is able to satisfactorily explain the phenomenon of accumulation of foreign direct investment. The final model estimated using Hausman-Taylor estimator explained FDI accumulation in nearly $81 \%$, while simple models using only classical

\footnotetext{
${ }^{2}$ Before 2001 new member states (EU-12) including V4 countries had been cut off from substantial FDI flows, there are a lot of gaps in databases. Also missing the most recent data (Pavlov, 2001; Karp, 1996).

${ }^{3}$ Infrastructure quality (spatial density of highways (Eggger \& Pffaffermayr, 2004; Roberto, 2004; Portes, Rey, 2005), cultural similarity (Buch et al., 2003), taxation (Egger \& Pffaffermay, 2004; Milner et al., 2004), unemployment rate (Szczepkowska \& Wojciechowski, 2002), membership in international organizations (Brenton et al., 1999; Lada \& Tchorek, 2008), GDP deflator (Szczepkowska \& Wojciechowski, 2002) and other variables.
} 
variables nearly explained only in $20 \%$ (Table 5). It suggests the importance of predicting FDI flows by taking into account individual characteristics of each country. In spite of increasing globalization, declining transport costs, it has been observed that the distance factor continues on flow of FDI. However, it has been observed that this effect was not equally strong in time. It has been noted that after 2005, negative effect of distance underwent successively. Also, the hypothesis of a negative relationship between the size of foreign investment in the country and the level of wage costs failed to verify. This may be due to the relatively low income diversification in the host countries. EU-15 countries behave in relation to V4 rather as market, efficiency and strategic assets seekers than resources seekers.

Table 5. The list of estimated models

\begin{tabular}{|c|c|c|c|c|c|c|}
\hline $\begin{array}{c}\text { Variable / } \\
\text { Measure }\end{array}$ & $\begin{array}{c}\text { Pooled } \\
\text { one way } \\
\text { individual }\end{array}$ & $\begin{array}{c}\text { One way } \\
\text { individual } \\
\text { within }\end{array}$ & $\begin{array}{c}\text { One way time } \\
\text { within }\end{array}$ & $\begin{array}{c}\text { Two ways } \\
\text { within }\end{array}$ & $\begin{array}{c}\text { One way } \\
\text { individual } \\
\text { random effects }\end{array}$ & $\mathbf{H T}^{\mathbf{4}}$ \\
\hline const. & $-45.86^{* * *}$ & - & - & - & $-31.540^{* * *}$ & $-16.4^{*}$ \\
\hline $\ln G D P_{i t}$ & $4.53^{* * *}$ & -0.21 & $4.47^{* * *}$ & 1.26 & $1.78^{*}$ & $2.26^{* *}$ \\
\hline $\ln G D P_{j t}$ & 0.58 & $2.75^{* * *}$ & -0.46 & $3.46^{* * *}$ & $2.13^{* * *}$ & $1.12^{* *}$ \\
\hline EMU $_{i j t}$ & - & - & - & - & - & $0.59^{* *}$ \\
\hline magrowth $_{j t}$ & - & - & - & - & - & $-6.01^{*}$ \\
\hline $\ln D I S T_{i j}$ & - & - & - & - & - & $-1.63^{* *}$ \\
\hline sea & - & - & - & - & - & $3.12^{* * *}$ \\
\hline $\boldsymbol{R}^{2}$ & $\mathbf{0 . 1 9 4 4 6}$ & $\mathbf{0 . 1 9 4 0 2}$ & $\mathbf{0 . 1 7 3 7 9}$ & $\mathbf{0 . 0 4 1 4 6 3}$ & $\mathbf{0 . 1 8 1 5}$ & $\mathbf{8 0 , 2 3}$ \\
\hline F statistics & $1012.7 \mathrm{p}<$ & $71 \mathrm{p}<$ & $67.3 \mathrm{p}<$ & $12.6 \mathrm{p}<$ & $72.1 \mathrm{p}<$ & $316,6 \mathrm{p}<$ \\
& $2.22 \mathrm{e}-16$ & $2.22 \mathrm{e}-16$ & $2.22 \mathrm{e}-16$ & $4.54 \mathrm{e}-06$ & $2.22 \mathrm{e}-16$ & $2.22 \mathrm{e}-16$ \\
\hline
\end{tabular}

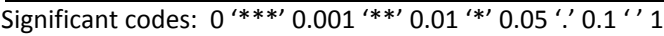

$\mathrm{sea}_{j}$ - binary variable 1 - country has got access to sea, 0 - others,

$E M U_{i j t}$ - each pair countries (partner and host) are in EMU in t- year -1, 0 others,

magrowth $_{j t}$ - average growth expressed by 3-year moving average of GDP per capita PPS yearly logarithmic rate.

Source: own calculations in R-studio.

\section{CONCLUSIONS}

It should be noted that Poland as a "FDI-attracting leader" plays a significant role in Central and Eastern Europe. Data show that Poland in 2011 was "interceptor" of the largest part of FDI invested by the old EU countries. Presumably Polish accession to the EMU would potentially accelerate FDI inflow in connection with the disappearance of currency risk. In fact, it seems very probable, when looking at the estimation model and the dynamics of cumulative FDI in Slovakia after joining the EMU the positive potential impact.

\footnotetext{
${ }^{4}$ In the LM test (King \& Wu, 1997) is found two-way effects presence. According Hausman test (comparing RE and FE model) the null hypothesis was rejected (chisq $=6.0548, \mathrm{df}=2, \mathrm{p}$-value $=0.04844$ ) Thus, the FE (while the alternative hypothesis is assumed that GLS estimator is loaded, and should use model fixed effect, the estimator does not show up unbiased). Baltagi test confirmed the presence of Li effects AR (1).Test Baltagi Li: rejection of the null hypothesis-occurrence effects AR (1) / MA (1) error RE.

It can be assumed that the extension of the model with autoregressive component would improve the quality of estimates and predictive properties of the model. However, this would require the use of another class of estimators.
} 
To sum up, gravity model seems to be a very useful analytical tool not only for researchers but mainly for economic policy, whose aim should be to create an appropriate mechanism for attracting foreign capital. Further research based on it seems to be very lucrative, taking into account the autoregressive dependences between variables as well as cointegration relationship and non-stationary of panel units.

\section{REFERENCES}

Ahmed, A.D., Cheng E., \& Messinis G., 2008, The Role of Exports, FDI and Imports in Development: New Evidence from Sub-Saharan African Countries, Centre for Strategic Economic Studies, Victoria University, Working Paper, vol. 13, no. 39, pp. 3-11.

Alan, A. \& Bevan, S.E., 2000, 'The determinants of Foreign Direct Investment in Transition Economies', William Davidson Institute Working Paper, no. 342, pp. 12-16.

Allen \& Overy LLP, 2006, Foreign Direct Investment in Central and Eastern Europe, London: Allen \& Overy LLP.

Anderson, J.E., 1979, 'A Theoretical Foundation for the Gravity Equation', American Economic Review, vol. 69, no. 1, pp. 106-116.

Babula, E. \& Kamińska, T., 2013, 'Does the Gravity Model Work as Regards FDI?' Proceedings of Annual Paris Business and Social Science Research Conference, Paris, France, 4 - 5 July 2013.

Babunek, O., 2012, 'Foreign Direct Investment in Visegard Four and the Main Traiding Partners', Statistika, vol. 49, no. 4, pp. 3-9.

Baltagi, B.H., 2005, 'Econometric Analysis of Panel Data', Chichester: Wiley \& Sons.

Brenton, P., Mauro F.D. \& Lucke M., 1999, 'Economic integration and FDI: An Empirical Analysis of Foreign Investments in the EU and in Central and Eastern Europe', Empirica, vol. 26, no. 2, pp. 2-13.

Brun, J.F., Carrere, C., Guillaumont, P., \& Melo, J., 2005, 'Has Distance Died? Evidence from a Panel Gravity Model', The World Bank Economic Review, vol. 3, no. 15, pp. 5-16.

Chamberlain, G. \& Moreira, M.J., 2006, 'Decision theory applied to a linear panel data model, Department of Economics - Harvard University, Cambridge, pp. 1-23.

Czarny, E. \& Folfas, P., 2011, 'Modele grawitacji jako narzędzie analityczne w ekonomii międzynarodowej', Portal Innowacyjnego Transferu Wiedzy w Nauce PITWIN, http://www.pitwin.edu.pl/.

Daszkiewicz N. \& Wach K., 2013. Małe i średnie przedsiębiorstwa na rynkach międzynarodowych, Kraków: Wydawnictwo Uniwersytetu Ekonomicznego.

Duce, M., 2003, Definitions of Foreign Direct Investment (FDI): A Methodological Note, Banco de Espana, Final draft, July 31.

Dunning, J.H., 1998, 'Location and the Multinational Enterprise: A Neglected Factor', Journal of International Business Studies, vol. 29, no. 1, pp. 50-53.

Egger, P. \& Pffaffermayr, M., 2004, 'The Impact of Bilateral Investment Treaties on Foreign Direct Investment, Journal of Comparative Economics, vol. 32, no. 4, pp. 3-13.

Estrin, S. \& Klaus, E.M, 2008, 'Foreign Direct Investment in Transition Economies: Strengthening the Gains from Integration', UN Conference Strengthening Integration of the Economies in Transition into the World Economy through Economic Diversification. 
Estrin, S. \& Millica, U., 2013, 'FDI into transition economies: are the Balkans different?' 12th EACES conference and the International Conference on occasion of the 75th Anniversary of the Faculty of Economics, University of Belgrade (Belgrade, 20-22 September 2012).

Folfas, P., 2011, 'FDI between EU member states: Gravity model and taxes', Warsaw: Warsaw School of Economics - Institute of International Economics.

Hausman, J.A. \& Taylor, W.E. 1981 'Panel Data and Unobservable Individual Effects', Econometrica, vol. 49, no. 6 , pp. 1377-1398.

Hunya, G. \& Richter, S., 2011, 'Mutual trade and investment of the Visegrad countries before and after their EU accession', Eastern Journal of European Studies, vol. 2, no. 2, pp. 4-11.

Iwasaki, I. \& Saganuma, K., 2013, 'A Gravity Model of Russian Trade: The Role of Foreign Direct Investment and Socio- Cultural Similarity', RRC Working Paper Series, vol. 4, no. 40, pp. 231 243.

Jambor, A., 2013, Country- specific determinants of horizontal and vertical intra- industry agrifood trade of the Visegrad Countries, FIW Working Paper, no. 104, pp. 34-49.

Julio, P., Pinherio-Alves, R. \& Tavares, J., 2013, Foreign Direct Investment and Institutional Reform: Evidence and an application to Portugal, Banco de Portugal Working Paper, vol. 2, no 6, pp. 232-241.

Karp, A.H., 1996, 'Time series magic: smoothing, interpolation, expanding and collapsing: time series data with proc expand', Sierra Information Services, Inc., San Francisco, California.

King, M. L., \& Wu, P. X., 1997, 'Locally Optimal one-sided Tests for Multiparameter Hypothesis'. Econometric Reviews, vol. 33, pp. 523-529.

Konstantinos, K., Matthew, G, Dimitrios, T, 2010, 'The Gravity Model Specification for Modelling International Trade Flows and Free Trade Agreement Effects: A 10-Year Review of Empirical Studies', The Open Economics Journal, 12-17.

Lada, K. \& Tchorek, G. 2008, 'Przepływy bezpośrednich inwestycji zagranicznych a utworzenie strefy euro', Available from:<www.nbpnews.pl/r/nbpnews/Pliki_PDF/NBP/ Publikacje /analityczne/LadaP.pdf> (accessed December 2013).

Mauro, F., 2000, 'The impact of economic integration on FDI and Exports: A gravity model approach', Center for European Policy Studies, Working document, vo. 3, no. 156, pp. 3141.

Paas, T. \& Tafenau, E., 2005, 'European trade integration in the Baltic Sea Region. A gravity model based analysis', HWWA Discussion Paper, vol. 3, no. 331, pp. 12-23.

Paniagua, J., 2011, 'FDI Gravity Equation: Models, Estimations and Zeros', Catholic Universyty of Valencia.

Pavlov, V., 2001, 'Missing Data and Interpolation in Dynamic Term Structure Models', Queensland University of Technology.

Porter, E. M., 1979, 'How Competitive Forces Shape Strategy', Harvard Business Review, vol. 12, no. 43, pp. 312-319.

Portes, R. \& Rey, H. 2005, 'The Determinants of Cross-Border Equity Flows', Journal of International Economics, vol. 65, No. 2, pp. 121-133.

Rajan, S. \& Hattari, R., 2008, 'Sources of FDI Flows in Developing Asia: The Roles of Distance and Time Zones', ADB Institute Working Paper, vol. 4. no. 117, pp. 4-7.

Suder, K. \& Sohn, H., 2012, 'FDI in Central and Eastern European Countries: Impact to Neighbors and Regional Agglomeration Effect', Preliminary Draft.

Szczepkowska, A., \& Wojciechowski, L., 2002, 'Możliwości wykorzystania modelu grawitacji do analizy bezpośrednich inwestycji zagranicznych w Polsce' In: Piech, K. \& Szczodrowski, G. 
(eds), Przemiany i perspektywy polskiej gospodarki w procesie integracji z gospodarkq światowq, Warszawa: Instytut Wiedzy, pp. 141-154.

Turan, S. \& Sotiros, B, 2013, 'Governance and Foreign Direct Investment in Latin America: A Panel Gravity Model Approach', Latin American Journal of Economics, vol. 50, no. 1, pp. 107-131.

Wach, K., 2012, Europeizacja małych i średnich przedsiębiorstw: rozwój przez umiędzynarodowienie, Warszawa: Wydawnictwo Naukowe PWN.

\section{Author}

\section{Liwiusz Wojciechowski}

Bachelor of International Trade, Econometrics and Computer Sciences, Spatial Planning (University of Gdańsk, Poland); Master in Econometrics and Computer Sciences, International Finance and Banking (University Gdańsk, Poland); Currently PhD student at the Faculty of Management of the Cracow University of Economics, Poland.

\section{Correspondence to:}

Mgr Liwiusz Wojciechowski

PhD Student at the Cracow University of Economics

Krakow, Poland

liwiusz.w@o2.pl

Published by Centre for Strategic and International Entrepreneurship - Krakow, Poland 